\title{
Praktek Dasar Kultur Jaringan Mamalia untuk Meningkatkan Wawasan Bioteknologi Di Man 2 Surakarta
}

\author{
Elisa Herawati, Okid Parama Astirin, Agung Budiharjo, Shanti Listyawati, Tetri Widiyani \\ Prodi Biologi, Fakultas Matematika dan Ilmu Pengetahuan Alam \\ Universitas Sebelas Maret, Surakarta \\ elisahera@staff.uns.ac.id,parama_astirin@yahoo.com,budiharjo_ag@yahoo.com, \\ shantilistyawati@staff.uns.ac.id, tetriwidiyani@staff.uns.ac.id
}

\begin{abstract}
Abstrak
Teknik kultur jaringan mamalia telah menjadi bagian tak terpisahkan dari bioteknologi modern yang diaplikasikan secara luas di lingkup biologi, kedokteran, dan farmasi. Di Madrasah Aliyah Negeri (MAN) 2 Surakarta, siswa jurusan IPA mendapatkan pengenalan bioteknologi secara teori di dalam mata pelajaran biologi, termasuk mengenai sejarah perkembangan dan aplikasi kultur jaringan. Karena kendala fasilitas dan sumber daya manusia yang terbatas, pembelajaran konsep-konsep kultur jaringan tidak pernah diimbangi dengan pengalaman praktek di laboratorium. Tujuan dari kegiatan pengabdian ini adalah: (i) meningkatkan wawasan umum mengenai bioteknologi, (ii) membantu pemahaman mengenai kultur jaringan mamalia yang tercakup dalam materi pembelajaran di sekolah. Metode pelaksanaan kegiatan adalah teori dan praktek di laboratorium Prodi Biologi UNS. Materi kultur jaringan difokuskan pada pengetahuan mengenai teknik aseptis, isolasi sel dari jaringan kulit, pemeliharaan kultur sel, dan pengamatan morfologi sel dengan mikroskop. Adapun selama KLB corona, praktek pengamatan jaringan hewan awetan dilakukan secara mandiri di rumah masing-masing menggunakan mikroskop kertas (foldscope). Dengan demikian, tiap siswa yang saat ini melaksanakan pembelajaran jarak jauh tetap mendapatkan kesempatan untuk praktikum. Hasil yang diperoleh dari kegiatan ini adalah tingkat pemahaman mengenai kultur sel dan jaringan yang lebih menyeluruh, serta pengalaman belajar yang lebih bervariasi untuk mengisi kekurangan pembelajaran jarak jauh yang minim praktek.
\end{abstract}

Kata Kunci: kultur jaringan, bioteknologi, foldscope

\section{PENDAHULUAN}

Kultur sel dan jaringan merupakan suatu metode dimana fragmen jaringan atau sel ditumbuhkan pada lingkungan artifisial yang baru (umumnya laboratorium) agar dapat terus tumbuh. Jaringan ataupun sel yang ditumbuhkan dapat berasal dari tumbuhan maupun hewan (Fresney, 2010). Aplikasi bioteknologi kultur jaringan telah dilakukan pada berbagai bidang. Kultur jaringan hewan misalnya, dapat menjadi metode untuk preservasi keanekaragaman spesies tertentu atau dapat juga dipakai dalam tahapan pengembangan obat (Herawati et al., 2020; Kakad et al., 2014). Kultur jaringan tumbuhan sendiri telah dimanfaatkan untuk kloning suatu spesies dan rekayasa genetika suatu tanaman (Espinosa-Leal et al., 2018).

Meskipun prospeknya menjanjikan, penerapan bioteknologi kultur jaringan masih terbatas pada kalangan tertentu seperti perusahaan besar(misalnya di bidang farmasi, pembimbitan), universitasuniversitas terkenal, dan lembaga penelitian bereputasi. Hal ini dikarenakan proses yang diperlukan untuk kultur suatu sel atau jaringan membutuhkan kondisi aseptis yang dapat diperoleh secara maksimal apabila dilakukan di laboratorium,

Pendidikan 810 
terutama bila menggunakan jaringan hewan. Di samping itu, diperlukan sumber daya manusia yang memiliki ketrampilan khusus di bidang kultur jaringan untuk mendukung keberhasilan aplikasi teknologi ini.

Program Studi Biologi, Fakultas Matematika dan Ilmu Pengetahuan Alam (FMIPA), Universitas Sebelas Maret (UNS) memiliki fasilitas yang cukup memadai untuk mengembangkan penelitian berbasis kultur jaringan. Laboratorium kultur jaringan hewan digunakan untuk kegiatan praktikum mahasiswa Biologi dan penelitian mahasiswa maupun dosen.

Penguasaan bioteknologi terapan, salah satunya kultur sel dan jaringan, menjadi relevan untuk siswasiswi sekolah menengah atau sederajat. Pertama, karena penguasaan di bidang ini bisa menambah kemampuan berwirausaha yang sangat penting untuk mencetak generasi masa depan yang mandiri. Contohnya pada wirausaha budidaya tanaman langka yang bernilai ekonomi tinggi. Tanaman langkadapat diperbanyak secara cepat dalam jumlah banyak melalui bioteknologi kultur jaringan. Kedua, teknologi kultur jaringan telah menjadi bagian penting dalam perkembangan dan aplikasi ilmu biologi modern. Misalnya dalam kasus pengobatan regeneratif menggunakan sel-sel punca, fertilisasi buatan, dan yang terbaru adalah genome editing yang juga menggunakan proses mengkulturkan sel embrio (Platt et al., 2014). Sadar akan pentingnya menambah wawasan dan menumbuhkan minat siswa terhadap bioteknologi terapan, Madrasah Aliyah Negeri (MAN) 2 Surakarta bekerjasama dengan UNS menyelenggarakan pelatihan kultur jaringan bagi siswa-siswinya.

Tujuan dari kegiatan pengabdian ini adalah: (i) meningkatkan wawasan umum mengenai bioteknologi, (ii) membantu pemahaman mengenai kultur jaringan mamalia yang tercakup dalam materi pembelajaran di sekolah, (iii) memberikan gambaran mengenai penerapan kultur jaringan mamalia untuk mengatasi persoalan masyarakat, (iv) menambah cakrawala dan wawasan mengenai atmosfer pendidikan di perguruan tinggi dengan cara berinteraksi langsung dengan dosen-dosen dan mahasiswa, (v) mengenal, eksplorasi, dan mencoba fasilitas laboratorium yang berkaitan dengan kultur jaringan, yang tidak dijumpai di sekolah.

\section{METODE}

Kegiatan ini dilaksanakan dengan model pelatihan yang dibagi menjadi tiga tahap. Tahap pertama adalah pengenalan materi kultur jaringan melalui teori di kelas. Tim P2M Prodi Biologi mengunjungi MAN 2 Surakarta untuk memberikan sesi pelajaran selama dua jam berupa teori dilanjutkan dengan diskusi.

Tahap ke-dua adalah praktek. Untuk dapat mempraktekkan teknik kultur sel, siswa MAN 2 berkunjung ke lab Biologi MIPA selama setengah hari. Sebanyak 40 siswa dibagi menjadi 8 kelompok, dan setiap kelompok mencoba teknik isolasi sel dan pemeliharaan kultur sel.

Tahap ke-3 adalah pengamatan jaringan hewan. Pada tahap ini, siswa diharapkan dapat mengamati langsung jaringan sel yang masih hidup. Adapun karena situasi Kondisi Luar Biasa (KLB) corona, maka model kegiatan dimodifikasi dengan praktek mandiri dari rumah masing-masing. Demi menunjang kegiatan praktek, tiap siswa difasilitasi dengan mikroskop origami yang dikenal dengan nama foldscope. Foldscope adalah mikroskop berbahan kertas, dengan lensa mini perbesaran $\times 162$ yang praktis dan ekonomis. Siswa merakit foldscope, kemudian melakukan pengamatan preparat awetan jaringan hewan yang juga diberikan sebagai satu set paket dengan foldscope. Sebagai bahan evaluasi, setiap siswa mengisi lembar kerja dan hasilnya dinilai untuk mengukur keberhasilan program dalam membantu pemahaman materi bioteknologi sesuai tujuan kegiatan.

\section{HASIL DAN PEMBAHASAN}

Kegiatan P2M ini secara keseluruhan menekankan praktek siswa dalam belajar Biologi. Konsep kegiatan yang disepakati adalah pengenalan (teori), praktek di laboratorium, serta praktek pengamatan jaringan awetan secara mandiri di rumah masing-masing. Kegiatan teori dan praktek laboratorium dilaksanakan pada awal bulan Februari 2020, sedangkan kegiatan pengamatan mandiri dilaksanakan pada bulan September sebagai solusi dari situasi KLB corona. 


\section{Pengenalan dasar-dasar kultur jaringan secara teori dan praktek}

Tim P2M Prodi Biologi berkunjung ke MAN 2 untuk menyampaikan materi selama dua jam dilanjutkan dengan diskusi. Antusiasme siswa terlihat dari banyaknya pertanyaan yang diajukan. Mayoritas siswa berpendapat bahwa topik kultur jaringan merupakan pengetahuan baru bagi mereka.

Praktek di laboratorium dilaksanakan pada hari berikutnya dimana siswa-siswi MAN 2 mengunjungi Lab Biologi FMIPA UNS. Siswa bekerja dalam satu kelompok dengan jumlah 6-7 siswa per kelompok. Dalam kegiatan praktek ini, siswa diperkenalkan dengan metode isolasi sel fibroblas dari telinga mencit (Gambar 1). Banyak dari siswa yang terlihat ragu-ragu karena di sekolah belum pernah praktikum dengan hewan mencit. Siswa juga diajarkan bagaimana memelihara sel yaitu dengan mengganti media pertumbuhan, bagaimana mengamati sel sehat dengan mikroskop, serta penerapan teknik aseptis selama mengerjakan kultur sel.

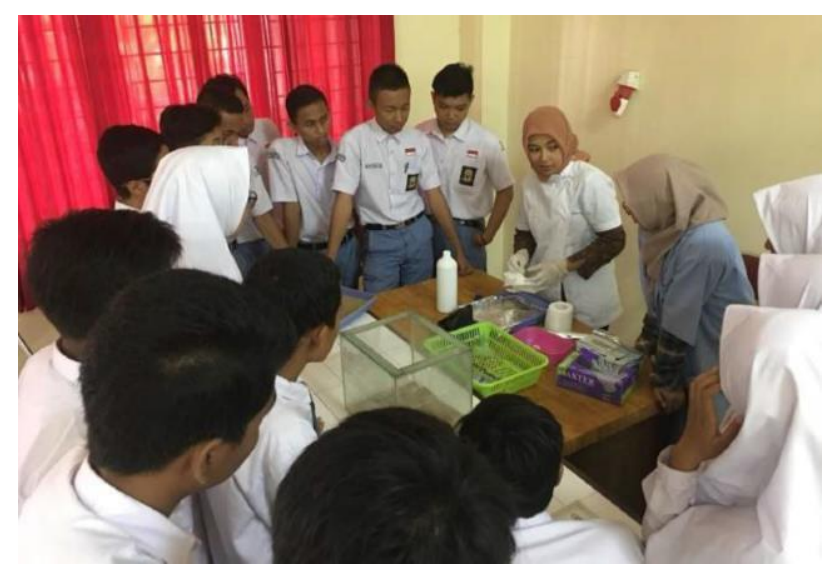

Gambar 1. Siswa-siswi sedang mendengarkan penjelasan mengenai teknik isolasi sel dari mencit.

Setelah semua kegiatan selesai, siswa diajak berkeliling laboratorium untuk mengenal berbagai macam alat yang tidak ada di sekolah mereka. Kegiatan teori dan praktek di atas merupakan satu kesatuan agar siswa mendapatkan pemahaman dasar kultur sel/jaringan secara utuh. Respon yang ditunjukkan oleh siswa sangat positif karena kegiatan dengan konsep Go to Laboratorium tidak hanya menambah ketrampilan dan wawasan siswa, tetapi juga siswa merasakan interaksi langsung dengan atmosfer pendidikan tinggi.

\section{Pengamatan jaringan hewan menggunakan foldscope secara mandiri}

Dengan adanya KLB corona, siswa MAN 2 telah melakukan pembelajaran jarak jauh (daring) selama enam bulan terakhir. Kendala pembelajaran daring adalah tidak terpenuhinya kompetensi praktek dikarenakan peralatan yang digunakan tidak tersedia di rumah masing-masing. Mempertimbangkan situasi KLB yang sangat dinamis, kegiatan P2M lanjutan dimodifikasi dengan melakukan praktek mandiri di rumah masing-masing.

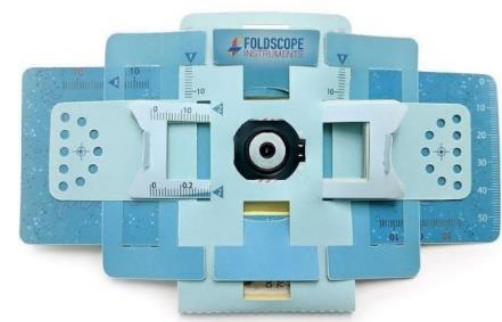

Gambar 2. Foldscope, mikroskop kertas origami yang dibagikan ke siswa untuk mengamati jaringan hewan di rumah masing-masing. Satu set media praktek berisi foldscope dan preparat jaringan usus

Alat yang digunakan adalah foldscope, yaitu mikroskop sederhana terbuat dari bahan kertas dengan prinsip origami (Gambar 2). Foldscope ini dikirim ke setiap alamat rumah siswa beserta dengan preparat awetan jaringan hewan yaitu jaringan usus dan jaringan kulit tipis. Siswa diberi panduan melalui zoom meeting, rekaman video, dan juga diskusi melalui grup whats app. Setelah mengamati preparatnya, siswa akan menulis hasil pengamatan pada buku kerja sebagai bentuk evaluasi. Hasil kuesioner tingkat kepuasan menunjukkan bahwa sebanyak 95\% siswa merasakan peningkatan wawasan bioteknologi. Keberadaan foldscope juga memberikan kesempatan kepada siswa untuk mengeksplorasi dunia sel yang tidak terbatas pada sel hewan saja, melainkan segala bentuk jaringan yang ukurannya mikroskopis seperti terlihat pada Gambar 3. 

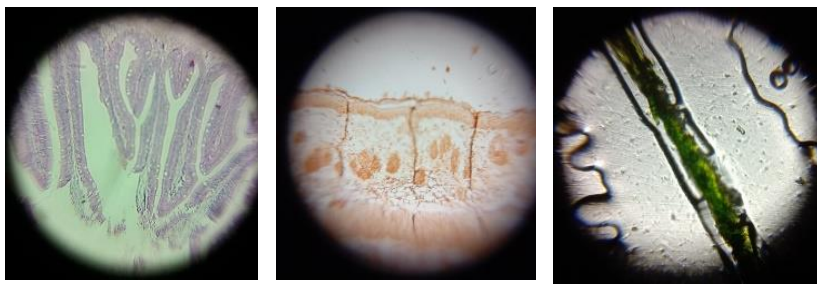

Gambar 3. Contoh hasil pengamatan mandiri oleh siswa menggunakan foldscope. Foto jaringan usus (kiri), jaringan kulit (tengah), dan irisan daun singkong (kanan).

Kreativitas siswa tampak dari hasil foto-foto yang dikirim ke Tim P2M. Mereka tidak hanya antusias mengamati jaringan hewan dari preparat yang disediakan untuk mereka, namun juga mengeksplorasi jaringan tumbuhan yang ada di sekitar tempat tinggal mereka. Dari hasil pengamatan, siswa berdiskusi dengan Tim P2M mengenai bagian-bagian sela tau jaringan yang mereka jumpai. Tim P2M juga memberikan kenang-kenangan kepada MAN 2 berupa empat belas set foldscope untuk digunakan sebagai media pembelajaran Biologi pada kesempatan lainnya (Gambar 4).

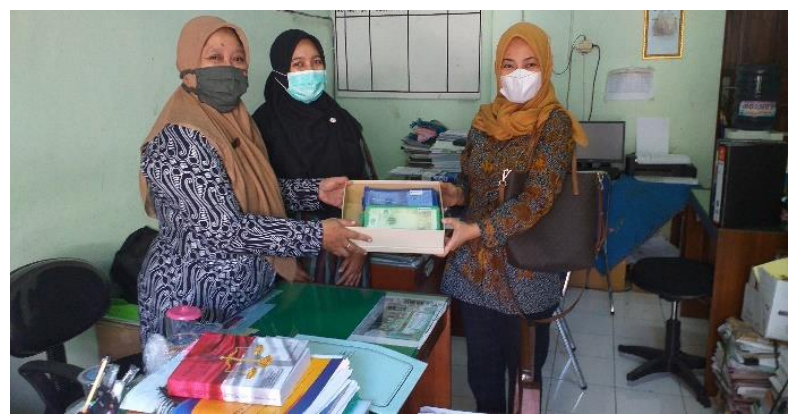

Gambar 4. Tim P2M menyerahkan sebagian foldscope kepada MAN 2 Surakarta.

Walaupun kegiatan ini berjalan dengan baik, namun Tim P2M juga mengalami kendala dalam pelaksanaannya. Mata pelajaran biologi yang diajarkan di tingkat sekolah menengah belum memfasilitasi pemahaman yang mendalam khususnya mengenai biologi sel, struktur dan perkembangan tumbuhan/hewan, dan fisologi tumbuhan/hewan. Tiga pokok bahasan tersebut sangat diperlukan untuk keberhasilan penguasaan teknik kultur sel dan jaringan. Kesulitan ini bisa diatasi dengan sering melakukan diskusi selama praktek, serta memberikan topik pelatihan yang sangat dasar.

\section{KESIMPULAN DAN SARAN}

Kegiatan P2M ini meningkatkan wawasan bioteknologi secara umum pada siswa MAN 2 Surakarta. Siswa mendapat pengetahuan dan ketrampilan baru terkait teknik kultur jaringan hewan. Kegiatan pembelajaran dengan fasilitas foldscope memungkinkan siswa mengeksplorasi berbagai unsur makhluk hidup yang berukuran mikroskopis, baik itu dari jaringan hewan maupun jaringan tumbuhan.

Mengingat manfaat yang diperoleh dari kegiatan praktek, saran untuk keberlanjutan kegiatan adalah komitmen penambahan jam praktek untuk mata pelajaran Biologi, tentunya disesuaikan dengan relevansi kebutuhan kurikulum yang diacu. Penyelenggaraan praktek (praktikum) dengan mengundang tenaga pendidik dari perguruan tinggi juga memperkaya pengalaman belajar siswa melalui perspektif yang berbeda.

\section{UCAPAN TERIMA KASIH}

Tim P2M Prodi Biologi FMIPA Universitas Sebelas Maret mengucapkan terima kasih kepada segenap guru dan siswa kelas 12 IPA MAN 2 Surakarta. Kegiatan ini terselenggara dengan pendanaan Hibah PNBP UNS Pengabdian kepada Masyarakat (Nomor: 453/UN27.21/PN/2020).

\section{REFERENSI}

Espinosa-Leal, C.A., Puente-Garza, C.A. \& GarcíaLara, S. (2018). In vitro plant tissue culture: means for production of biological active compounds. Planta 248, 1-18.

Freshney, R. I. (2011). Culture of animal cells: A manual of basic technique and specialized applications. Hoboken, NJ: Wiley-Blackwell.

Herawati, E., Wulandari, H., Listyawati, S., Etikawati, E. (2020). In vitro fibroblast cells culture from Pelung chicken embryo and its potential application. IOP Conf Ser Earth and Environ Sci (manuscript in press). 
Kakad, S.B. and Dhembare, A.J. (2014). The cytotoxicity of different plant extract on chick embryo fibroblast cell line. Arch Appl Sci Res. 6(4):139-142.

Platt, R. J., Chen, S., Zhou, Y., Yim, M. J., Swiech, L., Kempton, H. R., Dahlman, J. E., Parnas, O., Eisenhaure, T. M., Jovanovic, M., Graham, D. B., Jhunjhunwala, S., Heidenreich, M., Xavier, R. J., Langer, R., Anderson, D. G., Hacohen, N., Regev, A., Feng, G., Sharp, P. A., ... Zhang, F. (2014). CRISPR-Cas9 knockin mice for genome editing and cancer modeling. Cell, 159(2), 440-455. 
